SECTION 29. Literature. Folklore. Translation Studies.

Gulnoza Bobobekova

$3^{\text {rd }}$ year student of

Gulistan State University, Uzbekistan

aspirant-igm82@mail.ru

\title{
LITERARY MATTER IN MODERN POETRY
}

\begin{abstract}
The paper deals with the literary matter in modern rhyme and its imaginary problems, and also illuminated the formal and essential changes peculiarities of poetry are studied.
\end{abstract}

Key words: modern poetry, allegory, Epithet, lyric art.

Word art is in permanent development in the spirit of the age. Particularly, at present days Uzbek poetry represents a number of features. These changes can be observed in new area of poetry - modern poetry. Especially, it is another subject formal and essential changes, but its general features are invariable. In witness of this opinion it can be stated, that poem is "not opinion expression means, but art work and beauty of inspiration" [3, p. 249].

Particularly, in literary, also in poetry fundamental research object is life. "Literal panorama of human life" [1, p. 40] can be represented by means of pictures queens. Literary men write down thoughts, opinions, feelings, senses, viewpoints on the basis of their own observations. Reflection of life in created art works are represented by means of imageries. There are such notions as image and description in literature. "Image - is an image of human in art work, and imagery - is represents the essence of literal creative work and such general features, as literary characters, literary language, nature, subject, animal world description and others" [1, p. 40]. By poetizing, a poet first of all address the human and his interminable world - his life. Turn his eyes on it. He represents internal emotional experiences on the basis of own viewpoints and sensual world. As stated U.Normatov, "Real poets are the most sick among us, "sore among healthy men" and their sorrow is the sorrow of whole world, of human in fact" [3, p. 272]. These words of literacy critic fully represents the main point of creative work.

In the course of creation of the art work or poetry, it is very important work language for creator. "In his work, an author can achieve the imagery, picturesqueness of language by the various ways. One of them is to achieve the picturesqueness of language by means of clever application of representation means, special lexical recourses, poetic figures, casuistries” [1, p. 129]. These means obtains in art works, particularly, in poetic works. For example:

Oy desam oylaring singlimday,

Kun desam kunlaring ko'nglimday.

Nomingni aytsam - olam aro

Tog' topilmagay ko'ksimday [2, p. 12].

By these hemistiches, poet displays proud for native land. By the naming of native land, it is being represented by means of likening to proud in great lungsful. In this place, poet could just write simple phrase "I'm proud of my native land". No, he didn't, because impressionability of work closely associated with its picturesqueness. Her is coming out the question, what place has abovementioned literary picturesqueness means in poetry of $21^{\text {st }}$ century? Also, what approaching is being used in poetry of this period? It can be answered to these questions by creative of some poets.

In poem, which begins with line "Friends never understand you", of Ikrom Otamurod we can observe comparison it following context: 


\author{
Ishonch - singan misturlob, \\ mehr - zang bosgan tayg'u. \\ sodiq og'ang - iztirob, \\ qadrdon ining - qayg'u [2, p. 32].
}

Lyric character of this poem is poet himself. In poem it is been used of especial form of allegory. As is known, in this allegory form can be omitted some part. In the first line above allegory means is expressed by word "as": "Belief is as broken misturlob". In other parts of poem is this occurrence. This form of picturesqueness expression is being put into effect by "comparison of objects, phenomenon, notions with other objects, phenomenon or notions, which is ratherish has generality and similarity” [1, p. 152]. By using of this means, poet represents condition, in which men, even friends misunderstand each other. He stated with regret, that in this condition mercy and trust feelings are shake a stick at kicks the beam as broken misturlob, or feeling, became rusty. By confirmation of mentioned stating rises the emotionality of work.

In following distich of the poet comparison used by means of -day suffix:

Sumanbarday ketar ochilib,

Yomg'irdan so'ng osmon tarsillab.

In these lines there are used constituent part of allegory - assimilated object sumanbar, assimilating object - heaven, assimilative sign - clear up cracking and suffix -day. In this lines, the poet is trying to convey the condition after the raining to the reader. Also, in poem "Evrilish" of U.Hamdam used this literal expression means as above was used allegory in expression for "intensification of picturesqueness, exactness and emotionality":

Tarqoq tumanlardek sochildi yana,

Sochildi ko'ngilda tugilgan hayol.

In these lines too assimilated object - straggling fog, assimilating object imagination, assimilative sign - bearing and suffix -dek. By these lines, the poet expressed changes in human psychology. Complexity of feelings, impossibility of differentiation them into positive or negative, being bored from monotony, are essence, that the poet conscious of.

In following poem of the poet, which is written in human motive, also we can see expression of emotionality of feeling by trop:

Oqarmagan kunim - iztirob,

Yurgimga xanjardek kirgan!

By using the comparative literal means, the poet was able to provide the attractiveness and impressionability of poem.

There two original forms of comparative means:

a) traditional;

b) especial.

Abovementioned analyzes were examples for original comparison.

There are such "Traditional comparison means of assimilation from old written literature, as teeth with pearls, leaps with ruby or bud, face with moon, eyes with stars, figure with cypress and others, that can be used even at present by modern poets". This form of comparison can be observed in modern poetry too:

Bir mahliqo, husni malohatga kon:

Qad - shamshod, qoshlar yoy, mujgonlar - tug'xil.

1. In this poem of poet Otamurod image of beloved is drawn up on the basis of traditional comparison. As we can see in these examples, "comparisons can impart imagery, picturesqueness, exactness and emotionality to language of work". As analyzes has shown, changes in poetry doesn't have an effect on its main point. In other words, it is singular for modern poetry to aspiration for modernism without denying the traditionalism. 
One of the extended imagery means of work language is definition. This can be named epithet too. Definition - "word, defining, commenting, characterizing a object, events, notions and human in fiction". This notion is going to be used in poetry more and more. For example:

Bir odam... tiniq suvga tuproq tashlar - da, mazza qilarqilar loyqa bo'lganin ko'rib.

Wordforms "one person" and "clear water" in distich can be exampled for definition. By thinking on human being problem, the poet unto all human being he used "one person", as-if all human being is one person. Also, this person takes pleasure dirtying of "clear water", that is, from disturbing life of another people. Using a definition arouses up feeling of reader:

Kumush to'lqinlar tebranishida,

Shaffof manzillarning beshigi ishonch.

There are used such epithets, as "silver wave" and "clear addresses" in poem above. Picturesqueness in imagery can turn the readers on. As stated A.N. Tolstoy, "definition should very exactly and clearly draw up icy object, instantly appeared in the objective of photo camera”. This is inherent in creative work of modern poets too, indeed.

Zarrin shokilalarin kesib

Quyosh to'lar zulmat qarzini.

Epithet "flaring fringe" in essence of distich represents the meaning of sunbeams. As we can see from analyzes, definition has its own place among imagery means.

In modern poetry it's being widely used reviving imagery means. Revive - is "the way of imagery, appearance in the result of conversion of vital characteristics to inanimate being objects, natural phenomena, animal, birds”. For example:

Oqqushlar paryostiq berar keltirib,

Yetti qavat ko'rpa to'shaydi tovus.

Shundoq yonimizga ketadi qo'yib-

Oy tilla fonus.

In this poem conversed vital characteristics to swan, peacock and moon. Because of reviving lines, connected with human, that is inanimate being, this method is named "tashxis" (lyric art of rhyme). We can see this in following lines:

Qari daraxt tunlari notinch...

Tikiladi atrofga og'ir.

Uning ko'ksin tindalar o'kinch,

Shamollarga ochadi bag'ir.

Next type of reviving is named "intiq", in which main role played by "imaging object, unable to speak in the capacity ability to speak". This imagery means used to be widely used in classic and child literature:

Dil dedi: - Keturman ketmagin oso,

Azobdan qutilmoq yo'li go'riston.

Jon dedi: - Gar ketsang, kuzatguvchi oy,

Xonani berkitib suvab qo'yar loy.

Using of this imagery means serves to represent of image more brightly and exaggerate.

In modern poetry it is used to efficient use of periphrasis imagery means. In this type of imagery means "for speech expressiveness grossing purposes, names of objects, persons and events are swapped places with another words or wordforms, meaning their essence and features". For example: Cotton as like as white gold. In this example, to the thought attached literacy by the use of cotton features. Another example:

Yurak - shoirlar haqiqati -

Erkinlikka ruh bergan manzil.

Imagery means "poet's truth" in this distich is used in harmony with word heart. By means of using of periphrasis has been grossed emotionality of work. 
Or, in lines:

$$
\begin{aligned}
& \text { Kuz - g'amgin donishmand } \\
& \text { tillarning tillari - } \\
& \text { daraxtlarda hikmat so'ylayotir. }
\end{aligned}
$$

for purposes of more grossing of poems imagery, and awakening the feelings about autumn in reader, poet compared autumn with "mournful wise man", and trees with "light golden tongue”.

In modern poetry, abreast of many imagery mean's there can be observed tendency of lexical resources effective using. "Lexical resources can serve for enrichment of work language and grossing the imagery, emotionality of literal language”. Special lexical resources in language can gross imagery and picturesqueness of poems, indeed.

Kengliklar havosi musaffo, gardsiz,

Shabnamday beg'ubor,

Shabnamday tiniq.

In this poem are used synonyms, that is closest meaning of given words: clear, irreproachable, serene, clean. Here is synonyms are serving for adding transparence and attractiveness to image. Clearness of air enriched by means of comparative mean. In the second line of the following poem synonyms are serving for enriching its substantiveness.

Next example:

Yomg'irdan so'ng tarqar xilma-xil

Tashvishlar, siralar, tangliklar.

Zafar - mening o'zimman, biroq

Mag'lubiyat yonimdan ketmas!...

In this distich, is used one of the types of lexical resources, that is words contradicting each other, such: victory - defeat. Antonym words are serves to "developing an essence of word, represent of event more brightly and exaggerate”. In abovementioned distich image contradiction brightly represented by means of antonym words.

Kun yarmida tushar qorong'u

Qanday kechar tun borib - borib?!

In this distich is been used from antonym words "day" and "night". These words are meaningful in representing of character psychology. And with it, this method served to represent of work language more brightly and exaggerate. In classic literature antonym words are used to form tazod, tarse (lyric art of rhyme) in poems.

In addition with abovementioned, formatives of imagery can be also description of nature, objects and fauna.

As is known, mentioned descriptions are doesn't lose importance even at present. Particularly, using method of description of the nature can be described as scenery. In modern poetry we can meet various samples to scenery lyrics:

Kecha. Ko'rinadi na oy, na yulduz,

Shamol izillaydi chimdim yuzimni.

Daraxtlar soch yoyib shivirlar ma'yus,

Yo'qotib qo'yganman tamom o'zimni.

In this poem nature description represented in harmony with human mood. Description can represent even gloomy mood of character. Nature descriptions represents "vitality, literary, authenticity to work characters". And with it, they represents real psychology of lyric characters.

"Generalization of social phenomenon by means of objects, plants, things, fauna, colors" - forms symbolical images. For example: dove - is symbol of peace. Such samples can be observed great number:

Negadir bong urar 


\section{soat har lahza, Balki maqtanmoqchi bo'lar u vaqtni Hassaga suyangan chol - kampir esa - Otib yuborgisi kelar soatni.}

In this poem object clock is used as measurement of human life. Lyric character definitely understands, that any moment of life can't be returned back. By the means of clock details the poet tried to represent this feelings to reader.

Or, in following distich:

Qushcha, o'zimda yo'q narsani so'rab-

Juda xijolatga qo'yding odamni.

to imagery "bud" assigned a task of symbolical. In its basis, the poet represented heart phenomenon. Heart dreams of freedom only. But, here lyric character is powerless ...

We observed, that poet literally seized of life, and analyzed his addressing to various imageries. Impression, rendered to reader by created imagery depends on talent and diligence of the poet."

It is important for literal image to arouse emotions in reader. Exactly by means of it will be aroused positive or negative opinion of reader on the occasion of created work. For example, if during creation the image of nature scenes poet will use various means's and lingual resources, his work will far differ from works, in which wasn't effectively used of lingual resources. These two works will differ from each other by their lasting achievement. This shows, that it is very important the impressiveness and sensitivity of created image.

In conclusion, one of the most important especial features of not only poetry, but in general, of art literature has its own place and role in modern poetry. It can be characterized as especial form and method of life comprehension, "language" of art, also "judgement" on the life events. Its features can be observed in imagery means using in poetry, literal character, features of language, images of nature, objects, fauna. In this scientific issue as main research object pointed place of images, created by means of characters of literal language, particularly, literal imagery means, special lexical resources in modern poetry. Also researched importance and achievement of using them. During researches has been used creative works of such modern poetries, as I.Otamurod, X.Rustamova, U.Khamdam [10], T.Ali, A.Kutbiddin.

\section{The research paper was conducted under the scientific adviser:}

- PhD. Fayziyeva Obidakhon Kholbekovna, Gulistan State University (Uzbekistan).

\section{References:}

1. Boboyev T. Adabiyotshunoslikka kirish. - T.: O’qituvchi, 1979.

2. Ikrom Otamurod. Tag'azzul. - T.: Sharq, 2008.

3. Normatov U. Ijod sehri. - T.: Sharq, 2007.

4. Адабиёт назарияси. II жилдлик. II-жилд. - Тошкент: Фан, 1979.

5. Адабиёт назарияси. II жилдлик. I-жилд. - Тошкент: Фан, 1978.

6. Куронов Д. ва бошқалар. Адабиётшунослик луғати. - Тошкент: Академнашр, 2010.

7. Саримсоқов Б. Ўзбек шеър системалари хақида // Ўзбек тили ва адабиёти журнали, 1988.

8. Теория литературы. Том IV. Литературный процесс. - М.: Наследие, 2001.

9. Тимофеев Л.И. Основы теории литературы. - М.: Просвещение, 1976.

10. Улуғбек Хамдам. Янги ўзбек шеърияти. - Тошкент: Адиб, 2012.

11. Худойбердиев Э. Адабиётшуносликка кириш. - Тошкент, 1995. 